\title{
A preliminary analysis of microplastics in edible versus non-edible tissues from seafood samples.
}

Fleurine Akoueson ${ }^{\mathrm{a}, \mathrm{b}, \mathrm{x}}$, Lisa M. Sheldon ${ }^{\mathrm{a}, \mathrm{x}}$, Evangelos Danopoulos ${ }^{\mathrm{c}}$, Steve Morris ${ }^{\mathrm{d}}$, Jessica Hotten ${ }^{\mathrm{a}}$, Emma Chapman $^{\mathrm{a}}$, Jiana $\mathrm{Li}^{\mathrm{a}}{ }^{\mathrm{e}}$, Jeanette M. Rotchell $^{\mathrm{a}, *}$

${ }^{\mathrm{x}}$ Joint first authors

${ }^{a}$ Department of Biological and Marine Sciences, University of Hull, Cottingham Road, Hull, HU6 7RX, United Kingdom

${ }^{\mathrm{b}}$ Current position: University of Bordeaux, 351 cours de la Libération CS 10004, 33405 Talence CEDEX, France

${ }^{c}$ Hull York Medical School, University of Hull, Hull, HU6 7RX and University of York, Heslington, York, YO10 5DD, United Kingdom

d Department for Environment, Food and Rural Affairs, Seacole Building, 2 Marsham Street, London, SW1P 4DF, United Kingdom

${ }^{\mathrm{e}}$ Current position: State Key Laboratory of Estuarine and Coastal Research, East China Normal University, Shanghai 200062, China

Running title: Microplastics in finfish and shellfish

*Address all correspondence to: Jeanette M. Rotchell, phone number: +44 (0) 1482 465333, fax number: +44 (0) 1482 465458, e-mail: J.Rotchell@Hull.ac.uk

The authors declare that they have no actual or potential competing financial interests. 


\section{Abstract}

Plastics have been widely reported to be present in the environment yet there are still many questions regarding the extent of this and the impacts these may have on both the environment and human health. The purpose of this investigation is to determine levels of micro and mesoplastic (MP), in the 1-5000 $\mu \mathrm{m}$ range, in commercially important species of finfish and shellfish. Additionally, to determine and compare the relative MP levels in edible versus non-edible tissues, and consider the wider implications in terms of human health concerns with a preliminary risk identification approach. For several fish species, samples taken from typically non-edible (gills, digestive system) and edible (muscle) flesh, and were analysed separately. Scallops, where all tissues are edible, were analysed whole. Significant differences were observed in the number of particles isolated from the finfish gills and digestive tissues relative to the control samples, but not in the edible flesh. For scallop, the abundance of particles in the Scottish samples did not vary significantly from the control, while the Patagonian scallops displayed significantly higher numbers of MPs. Characterisation of MPs by FTIR microscopy found that 16-60\% (depending on species) were polyethylene terephthalate (PET) and polyethylene (PE) in origin. The risk identification results validate MPs as an emerging risk in the food chain and establish seafood as a vector for the exposure and uptake of MPs through the ingestion route for humans. Levels of MPs in seafood, and a direct link to the human food chain, suggests that their quantification be included as one food safety measure.

Keywords: microplastics; seafood; edible flesh, risk 


\section{Introduction}

The global presence of plastics in the marine environment is well documented. MPs are generally defined as be plastic particles measuring 1 to $1000 \mu \mathrm{m}$ across the longest dimension, although some count any plastic particle less than $1 \mathrm{~mm}$ across and/or from 1-5 $\mathrm{mm}$ in size (Browne et al. 2010; Van Cauwenberghe et al. 2015; Hartmann et al., 2019). Macro-, meso, and micro-sized plastics are found throughout the world's oceans from beaches and coastlines, to subtropical oceanic gyres, polar ice caps and the deep ocean (for review: Wright et al. 2013; Law and Tompson 2014; Cole et al. 2014; Waller et al. 2017). This has led to the incidence of plastics in sediments of areas used to cultivate commercial bivalves and finfish (Kazmiruk et al. 2018), as well as in natural ecosystems of marine biota (Nor and Obbard 2014). Some of these particles originate from the cosmetic and hygiene industries and products in the form of microbeads (Fendall and Sewell 2009) and are generally referred to as primary plastics as they enter the ocean already at a microscopic size (Cole et al. 2011; Hartmann et al. 2019). However, many plastics start out as macroplastics, and break down over time in the ocean water through exposure to UV light (Ryan et al. 2009), these are referred to as secondary plastics (Cole et al. 2011; Hartmann et al. 2019).

The primary environmental risk associated with plastics is their availability (Wright et al. 2013; Desforges et al. 2015). Multiple marine species, including their different life stages, have now been reported to ingest plastics from the environment (Thompson et al. 2004; Browne et al. 2008; Boerger et al. 2010; Murray and Cowie 2011; Foekema et al. 2013; Lusher et al. 2013; Steer et al. 2017). This includes species of commercial fish and shellfish seafood products for human consumption (Tables S2 and S3), which represents an exposure route for humans with possible but currently unknown health implications that are not yet fully understood (Rochman et al. 2015; Van 
Cauwenberghe and Janssen 2014). Of the studies to date there has been a greater diversity of finfish species investigated (Table S2), while more studies in total have been conducted using shellfish (Table S3). Many of these studies provide only a baseline for further study, particularly for finfish, where few of the species have had repeat observations. Also, the majority of previous studies do not separate the typically edible from non-edible tissues prior to analysis.

Lab-based exposure studies into impacts associated with plastics exposure in animals have been carried out including behaviour changes (de Sá et al. 2015), and physiological changes (Van Cauwenberghe et al. 2015). Findings have suggested that the consequences can range from a loss in predatory performance, such as Common goby, Pomatoschistus microps, struggling to identify prey items following MP exposure (de Sá et al. 2015), to increased energy consumption of Blue/Common mussel, Mytilus edulis (Van Cauwenberghe et al. 2015). However, there is uncertainty as to whether such research has used environmentally relevant exposure conditions (von Moos et al. 2012).

In this study, we examine the levels and types of micro- and mesoplastics (MPs) in seafood samples intended for human consumption (by sale at supermarkets) from a commercial supplier source. The aims are threefold: to determine the MP tissue burdens in selected commercially important finfish and shellfish species; to compare levels in the edible flesh relative to the non-edible tissues; and, by applying a preliminary risk-based assessment approach, to determine the potential human health impacts. The rationale for this approach is to provide a level of assessment of the potential for human exposure to MP via ingestion of seafood. 


\section{Materials and Methods}

\subsection{Sample source}

Scottish haddock (Melanogrammus aeglefinus), Greek seabass (Dicentrarchus labrax), Icelandic plaice (Pleuronectes platessa), Atlantic mackerel (Scromber scombrus), Patagonian scallop (Zygochlamys patagonica) and Scottish scallop (Pecten maximus) ( $\mathrm{n}=10$ individuals for each species with the exception of $n=12$ for haddock, and $n=10$ (that were subsequently processed in two subsamples due to their larger size) for Scottish scallops, were provided by a commercial producer (Supplemental Table S1). For the fish species, pre-dissection of the gill, gut and edible flesh tissues were conducted within a sterile laminar flow fume hood at the commercial producers facility. Scallops were provided de-shelled and whole. Length and weight measurement data, taken prior to dissection, for each fish was also recorded (Supplemental Table S1). On receipt, the fish tissue samples were further minced with scissors in a sterile laminar flow fume hood, and $\sim 5 \mathrm{~g}$ of soft tissue from each then digested. Scallops (whole) were similarly chopped using scissors before digestion.

\subsection{Hydrogen peroxide digestion treatment of soft tissue}

The digestion extraction methods and analysis of particles from samples were based on Li et al. (2018). For each sample, the minced soft tissue ( $\sim \mathrm{g}$ by weight for fish, scallops whole) was placed in a $1 \mathrm{~L}$ conical flask. Ten replicates were digested for each species. Next, $200 \mathrm{~mL}$ of $30 \% \mathrm{H}_{2} \mathrm{O}_{2}$ were added to each conical flask, and the flasks were covered with foil and placed in an oscillation incubator at $65{ }^{\circ} \mathrm{C}$ at $80 \mathrm{rpm}$ for $24 \mathrm{~h}$ and then at room temperature for 24 to $48 \mathrm{~h}$ depending on the digestion status of the soft tissue. All liquids (hydrogen peroxide) were filtered with a $1 \mu \mathrm{m}$ filter paper (Whatman qualitative filter paper No. 1, supplied by Camlab Ltd., Cambridge, UK) prior to use to reduce contamination of the samples by airborne MP. The digestions were terminated once 
they appeared clear with no obvious large particles visible, and then filtered with a $5 \mu \mathrm{m}$ pore size, $47 \mathrm{~mm}$ diameter cellulose membrane filter (EMD Millipore, Fisher Scientific, U.K.). Filters were removed from the filter assembly using sterile tweezers and stored until microscopy analysis. A procedural blank extraction ( $\mathrm{n}=6$ replicates) without tissue was performed simultaneously to identify and characterize any extraneous MP contamination during the digestion step.

\subsection{Observation and validation of MPs and other anthropogenic or natural source particles}

The filters were observed under an Olympus SZX10 Research High-Class Stereo microscope (Olympus Corporation, Japan), and photographed with an Olympus UC30 digital camera. A visual assessment was conducted to identify particles according to the physical characteristics. MPs were classified as fibers, film, fragments or spheres using the descriptions from Tagg et al. (2015). A number of commonly detected particles were selected and verified with a micro-FT-IR, iNicolet, Thermofisher Scientific) cooled with liquid nitrogen (Tagg et al. 2015). Analysis was conducted in transmittance mode with MPs mounted on a diamond compression cell. Spectra were acquired and matched using a series of polymer library databases (Hummel), a hit index of at least $70 \%$ was considered acceptable.

\subsection{Statistical analyses}

Statistical analyses were performed using Statistical Package for the Social Sciences (SPSS) and R. Any differences of the abundance of total MPs, and total fibers alone, in tissue samples was determined using Kruskal Wallis test for non-parametric datasets. Statistical significance was accepted at $*=p<0.05, * *=p<0.01, * * *=p<0.001$. The data are presented without the subtraction of, and alongside, the procedural blank values to promote transparency.

\subsection{Preliminary risk identification of MPs in seafood}


A preliminary food safety risk analysis has been carried out based on the English food safety legislative framework which encompasses the European Union Regulation 178/2002 on food safety (European Commission 2002), the UK General Food Regulations (2004) and the English Food Safety and Hygiene Regulations (2013). The risk analysis included an emerging risk identification (ERI) procedure (EFSA 2014). Further details regarding the definitions and methodology used in the ERI procedure and the risk analysis are described in Supplemental Information Methods S1.

\section{Results}

\subsection{Particle type, abundance and distribution in fish tissue samples.}

Particles were detected in all replicate fish tissue and procedural blank (control) samples (Figure 1). In terms of procedural contamination, particles from airborne fibres ranged from $0.02 \pm$ 0 to $0.8 \pm 0.131$ items/filter ( \pm standard deviation). In terms of significant differences, the number of particles isolated from haddock gills (yet not the flesh or digestive tissues) were increased compared to the procedural blank ( $p=0.009)$. The seabass digestive tissues contained significantly higher levels of particles relative to the blank $(p=0.001)$ and also the haddock digestive tissues $(p=0.03)$. The mackerel samples showed no significant differences from the procedural blank yet the haddock gill tissues contained significantly higher number of particles $(p=0.025)$ compared with the lower value for mackerel gill tissues. The plaice samples also revealed no significant differences from the number of particles isolated from the blank, although the plaice digestive tissues contained significantly more particles $(p=0.017)$ when compared with the mackerel digestive tissues. The edible flesh samples derived from each of the fish species showed no significant differences from the number of items isolated from the respective procedural blank samples.

\subsection{MP abundance and distribution in whole scallop tissue samples}

The numbers of particles detected in scallop tissues are shown in Figures 1 and 2. These values 
are relative to a procedural blank value of $0.19 \pm 0.18$ items/filter. The abundance of particles in the Scottish scallops did not vary significantly from the procedural blank, while the Patagonian scallops displayed significantly higher numbers of particles relative to both the blank and the Scottish scallops ( $p=0.000$ for both). Comparing the Patagonian scallops with the various fish digestive tissues (Figure 1), a significantly higher number of particles were observed in the Patagonian scallops relative to the mackerel, plaice and haddock digestive samples, but were similar to the seabass digestive tissue values observed. For flesh comparisons; Patagonian scallop samples contained significantly more particles compared with all the fish flesh samples $(p=<0.003)$ and Scottish samples were significantly lower (all $p=0.000$ ) compared with three of the fish species but displayed a similar abundance with the mackerel.

\subsection{Chemical characterisation of the particles identified in tissue samples}

The types of particles identified in the fish tissues varied as follows. Fibres were the most abundant particle throughout all samples (Figure 3), representing approximately $90 \%$ of all items in mackerel. Fragments were the next most represented, followed by very small incidences of film or spheres. The latter were only identified in Plaice samples (Figure 3). A similar pattern of particle types was observed in the scallops: fibres $>$ fragments $>$ spheres (Figure 3). The smallest size range of particles $(5-25 \mu \mathrm{m})$ was represented most in the fish tissue samples (Figure 4), which contrasts the scallop findings where larger particles (of the size range 500-5000 $\mu \mathrm{m}$ ) were more abundant (Figure 4).

Micro-FT-IR spectroscopy was conducted on randomly selected fish and scallop sample particles. For the fish samples, a total of 601 unknown items were isolated from all tissues and of these, 96 were chemically characterized (representing $16 \%$ of the sample set). For scallop, a total of 372 unknown items were isolated from tissues and, of these, 101 items were chemically characterized ( $27 \%$ of the sample set). From the procedural blanks, 27 and 12 particles were isolated alongside the fish and scallop analyses respectively, and were identified as 
cellulose/cellophane fibres or, in two instances polyethylene terephthalate (PET), and one instance each as zinc stearate/polyacrylonitrile/polyolefin.

Overall, the spectra found that $17-59 \%$ of these particles characterized were made up of MPs in the fish tissues analysed depending on the species: haddock $20 \%$, seabass $17 \%$, mackerel 50\% and plaice 59\% MP. Of the MPs detected, PET and polyethylene (PE) were the most common in fish tissues (Figure 5). With respect to the scallop samples analysed: 60\% and 16\% were of MPs/semi-synthetic composition in the Scottish and Patagonian sourced samples respectively (Figure 5).

\subsection{Summary of a literature review of MPs in fish and shellfish}

Approximately 31 papers recently published specifically investigate MPs in finfish and shellfish (Supplemental Tables S2 and S3). There has been a more focused approach carried out on a few shellfish species, compared to large numbers of studies using many finfish. Many studies provide a baseline for further study, particularly for finfish, but have few repeat observations. Relevantly to this study, the majority of previous studies do not separate the typically edible from non-edible tissues prior to analysis. In terms of geographical distribution, there have been a high number of shellfish studies around European coastlines compared to the rest of the World, this is in contrast with African coastlines and the Oceania region where there has been a lack of investigation (Figure 6). There have been several studies conducted along the coastlines of North and South America (Boerger et al. 2010; Davidson and Dudas 2016; Liboiron et al. 2018; Mathalon and Hill 2014; Possatto et al. 2011; Rochman et al. 2015; Santana et al. 2016) (Figure 6), but there are still large areas of the Americas which have not been studied at all, and some studies did not quantify the MP concentration in the organisms (e.g. Rochman et al. 2015). The finfish studies are less concentrated in one area but there are still no studies from Africa's coastline or in Australasia (Figure 6). Plus, 
while there are some studies carried out along Chinese coastlines and in the East China Sea (Li et al. 2015; Li et al. 2016; Jabeen et al. 2017), there has only been a single study conducted in Japan (Tanaka and Takada 2016) (Figure 6).

\subsection{Risk assessment of MPs in seafood}

The outcome of the ERI procedure identifies MPs as an emerging risk (Figure 7A) subsequently triggering a full risk assessment (Figure 7B). The conceptual model takes into consideration the unique characteristics of MPs found in seafood intended for human consumption (Figure 7B) and is informed by relevant guidelines that are already used for other contaminants in the assessment of environmental risks and drives (FDA 2002; SCENIHR 2012; EFSA Scientific Committee 2017; 2018). A major component of the risk assessment procedure is establishing an exposure/uptake route, and looking at the findings of this study and the data from the literature review regarding the presence of MPs in seafood (Tables S2 and S3), it is clear that there is evidence to support human exposure to MPs through the ingestion uptake route and identify seafood as a vector of MPs into the human body. Quantification of the exposure can be derived from seafood consumption data. In the UK, the weekly quantity of household purchases per person ( 136 $\mathrm{g})$, and the takeaway food brought home ( $\sim \mathrm{g})$ add up to a weekly consumption of $145 \mathrm{~g}$ per person, or $7.54 \mathrm{~kg}$ per year (DEFRA 2017). The Food and Agriculture Organization (FAO) of the United Nations reports a much higher consumption of fishery products in the UK at $20.8 \mathrm{~kg}$ per capita per year (for 2013) (FAO 2016). Modelling consumption and exposure rates provides an exposure assessment to MPs attributed to seafood (Table S4). According to the findings of this study for whole shellfish and fish (edible) flesh tissues, taken together with the DEFRA consumption rates, the lowest would be 1,267 MP items per year and the highest 5828 MP items per year, derived from 
the incidence of MPs in Scottish scallops and plaice, respectively (Table S4). Using the consumption rates from FAO (FAO 2016), this extrapolates the lowest yearly exposure to 3,494 MP items per year and the highest to $16,076 \mathrm{MP}$ items per year from the same seafood species. The limitations of this exposure assessment include the small sample of the present study, and that consumption does not differentiate between different types of seafood and species. Also, regarding the results on the flesh of the fish, the MP content could be attributed to the very low level (but still present) airborne sample contamination in the lab environment. The next step of the risk assessment is to interpret how this exposure relates to human health effects, especially in the long term as well as health effects throughout the life course.

\section{Discussion}

\subsection{Abundance and distribution of MPs in fish and shellfish samples}

This study provides a report of MPs, and other natural and semi-synthetic items, in the fish tissues and shellfish samples supplied. The results from the seafood samples analysed have been further separated into typically edible and non-edible tissues to determine the relevance to human consumption. Compared with the procedural blank, low levels of particles have been observed in the majority of fish samples regardless of tissue source (with less than $\sim 1$ item per gram). However, significantly increased numbers of particles were observed in the seabass digestive gland and haddock gills relative to their respective blank samples, tissues that would not normally be consumed by humans. Regarding the procedural blank background levels of contamination, particles from airborne fibers ranged from $0.02 \pm 0$ to $0.8 \pm 0.131$ which compares favourably with our past average of $2.17 \pm 1.47$ items/filter for previous mussel analyses conducted in our lab (Li et al. 2018). The lowest incidence of MPs detected in typically edible fish tissues (from mackerel flesh) 
extrapolates to an incidence of approximately $30 \mathrm{MP}$ or semi-synthetic items per $100 \mathrm{~g}$ serving of flesh for mackerel. This assumes an even distribution of $\sim 0.6$ particles per gram and a MP rate of $50 \%$ based on the FTIR findings. The highest incidence of MPs detected using the Patagonian scallop, which are consumed whole, also extrapolates to an incidence of approximately $30 \mathrm{MP}$ or semi-synthetic items per $100 \mathrm{~g}$ serving, assuming an even distribution of $\sim 2$ particle per gram and a MP rate of $16 \%$ based on the FTIR findings.

In this analysis, MP and other semi-synthetic items have been identified in every tissue type. Looking at rates of items per individual: all of the fish flesh samples contained particles, with the exception of mackerel flesh where only $70 \%$ of the samples analysed contained particles, and $100 \%$ of both scallop samples contained particles. While keeping in mind the small sample set involved: for haddock, 20\%; seabass, 17\%; mackerel, 30\%; plaice, 50\%; Scottish scallop, 60\%; and Patagonian scallop, $16 \%$ of items analysed were chemically characterised as MPs.

\subsection{Comparison with published worldwide field investigations: finfish}

For the fish samples herein, these rates compare with a report for Thames Estuary caught flounder (Platichthys flesus), a similar bottom feeder flatfish to the plaice, where $75 \%$ of individuals contained MPs (McGoran et al. 2017) compared with 100\% for the plaice reported here. In contrast, others report significantly lower levels of MP contamination in bottom dwelling North Sea fish species, amounting to only $0.5 \%$ of grey gurnard (Eutrigla gurnardus)(Foekema et al. 2013), and 0\% abundance for common dab (Limanda limanda) analysed (Hermsen et al. 2017). These authors attribute low abundances to strict quality assurance criteria in reducing background contamination, yet our procedural blank data suggests that reducing such background, even using quality assurance approaches, to zero is not possible (Foekema et al. 2013; Hermsen et al. 2017). In support of our findings, another study conducted further offshore, reported that $47.7 \%$ of the bottom dwelling 
flatfish European plaice (Pleuronectes platessa), and 51\% for plaice sampled from the North East Atlantic around the Scottish coastline (Murphy et al. 2017) contain MPs. One important consideration however, is that all of these collective previous studies do not differentiate between typically edible and non-edible tissue sources from the fish sampled and analysed, their results are expressed as MPs incidence from digestive tissue samples only. The only other current study to differentiate between edible and non-edible tissues from commercially caught fish, reports a similar finding to those herein, whereby Asian seabass (Lateolabrax maculatus) have significant microplastic contamination in the guts and gills, yet not in the muscle/flesh relative to the level determined for the procedural blank (Su et al. 2019).

Trophic level and feeding strategy may account for the observed differences in MP levels. Ory et al. (2017) suggested that predatory finfish were selective in what MPs they consumed, choosing particles which most resembled prey items in colour. This is also supported by the lab study which found juvenile fish would consume more plastic if it was the colour of their prey and would then struggle to identify actual prey (de Sá et al. 2015). This could suggest that filter feeding bivalves may ingest MPs in greater numbers as they passively ingest the particles while filtering water, rather than choosing particles to consume, while finfish may avoid some MPs. On the other hand, predatory species such as haddock, mackerel, and sea bass would be likely to take up MPs when consuming prey with biomagnification along trophic levels. Yet Liboiron et al. (2018) found silver hake, a finfish predator, to have no incidence of MP contamination.

When considering the literature assembled thus far there has been a range of dietary preferences studied for finfish; from omnivorous Liza haematocheila (Jabeen et al. 2017), to carnivorous Mullus barbatus (Bellas et al. 2016), to planktivorous Decapterus muroadsi (Ory et al. 2017). When considering a study which looked at a range of species along Chinese coastlines the species identified as carnivores did not appear to have a significantly higher MP content than the omnivore species, with the range for omnivores found to be $0.5 \pm 0.2-10.1 \pm 4.9 \mathrm{MP} / \mathrm{g}$ and for carnivores $0.4 \pm 0.2-17.2 \pm 9.7 \mathrm{MP} / \mathrm{g}$ (Jabeen et al. 2017). In the case of $D$. muroadsi there was a 
high ingestion rate of MPs which resembled the colour of the plankton they would usually consume, which appeared to suggest the fish were direct consumers of the MPs rather than accumulating them through trophic transfer (Ory et al. 2017). That said, several trophic transfer investigations have reported higher MP levels in predatory organisms (Setälä et al. 2014; Welden et al. 2018). For example, predatory species of molluscs were found to have ingested a higher concentration of MPs than non-predatory molluscs (Naji et al. 2018). However, this does not appear to be the case across all biota as Welden et al. (2018) found no significant difference between the MP content of the prey species Ammodytes tobianus, and its predator Pleuronectes platessa, and concluded that the predator species did not retain MPs taken up when consuming the prey.

Karami et al. (2018) considered the MP content of canned sardines and sprats after processing. The abundance of MPs in the cans was found to be relatively low, with complete absence in 16 brands and between 1-4 MPs in the 4 other brands. This may also suggest that following the gutting and processing procedure the number of MPs is reduced and so canning may be a relatively safe way to consume seafood. However, it is also worth considering that this study used Raman spectroscopy which has previously failed to identify plastics when there are colourants present in the material (Van Cauwenberghe and Janssen 2014).

\subsection{Comparison with published worldwide field investigations: shellfish}

In comparison with our previous mussel tissue analysis, a similar trend has been observed when compared with the scallop samples. For mussels (which are filter feeders), half of all particles (50\%) characterized were confirmed to be MPs and included polyester, polypropylene and polyethylene (Li et al. 2018). Polyester was the dominant polymer type in mussels sampled from the environment, while polypropylene was the most prevalent type in farmed mussels (Li et al. 2018). An additional $37 \%$ of particles were made up of rayon and cotton fibres as well as a natural/synthetic blend of cotton and olefin and were considered to have an anthropogenic origin, whilst only $\sim 10 \%$ were 
confirmed to be naturally occurring cellulose ( $\mathrm{Li}$ et al. 2018). For the scallops analysed in this study, PET was the most prevalent MP, though polyethylene and polypropylene are also represented. In contrast to our previous mussel work, cellophane/cellulose occur at a significantly higher prevalence of up to $20-85 \%$ in the two scallop species compared with mussels. It is important to note that FTIR analysis of 'cellulose-type' materials that have been weathered (or have gone through a digestive system) are difficult to identify with absolute certainty as either cellulose or cellophane.

\subsection{The impact of methodological approach on reports of MP abundance levels in seafood}

As the field is still relatively new it could be expected there may be some issues with the methodology that make data comparisons difficult. In terms of processing organisms there are two different acids used to dissolve the tissues; $\mathrm{H}_{2} \mathrm{O}_{2}$ (Bonello et al. 2018; Li et al. 2018; Naji et al. 2018) and $\mathrm{HNO}_{3}$ (De Witte et al. 2014), a base such as $\mathrm{KOH}$ may also be used (Foekema et al. 2013; Phuong et al. 2018). A study considered whether prolonged exposure of anthropogenic debris to different chemicals would cause loss of some materials, finding that nylon was underrepresented when samples were treated with $\mathrm{HNO}_{3}$ (Claessens et al. 2013), so use of different methods could make some studies incomparable. Some of the studies conducted thus far have also not carried out chemical analysis on the items identified as anthropogenic to show whether they are a MP (Rochman et al. 2015), resulting in overestimations.

Van Cauwenberghe and Janssen (2014) identified plastic types using Raman spectroscopy, which created spectra of the colourants used in the plastics, not identifying the plastics themselves, and potentially leading to overestimations. In selected finfish studies no further analysis of the particle types was attempted. An alternative is FTIR micro-spectroscopy, as employed in this investigation and by others (Claessens et al. 2011; Li et al. 2018). However, neither of these analysis methods can identify particles in the size range of $20 \mathrm{~nm}$ to $10 \mu \mathrm{m}$ (GESAMP 2015), leading to a failure to 
$\overline{\text { identify many MPs, and those in the nanoplastics size range. This may be especially relevant for }}$ filter feeding bivalves, as well as the finfish gills and digestive system, where crossing cell membranes, and entering the bloodstream become possible.

\subsection{Human exposure levels of MPs via seafood and risk assessment}

To recap, all samples analysed, with the exception of a minority of the mackerel flesh samples, contain particles. The gill and digestive gland tissues from the four finfish analysed contain more MPs compared to the edible flesh samples from the same fish, reducing the potential for human consumption. On closer examination of a subset of the particles isolated, it has been possible to predict the incidence of MPs for each species analysed, which are relatively low compared with some international studies and similar to a number of previous UK studies. Critically, relative to the background levels of MPs (identified in the procedural blanks), there were no significant levels in the edible flesh of the four finfish species analysed, nor in many species of finfish reported in published studies. This was not the case for shellfish however, where all of the shellfish species investigated were confirmed to uptake MPs, even when some individual animals were found to not contain MPs (Santana et al. 2016). The implications of these low levels of MPs in shellfish in particular, either in terms of consumers' perceptions, or actual health impacts, are currently unknown.

When considering the countries as having the greatest fish catch rate in tonnes, namely; China, Indonesia, USA, Peru, Russian Federation and Japan (Richardson et al. 2016), the lack of understanding on how much plastic is being consumed by humans becomes clear. For instance, at this moment, only one study on a single species has been conducted along the coastline of Japan (Tanaka and Takada 2016) despite this being among the countries with the highest catch rates.

Although, all the stages of the risk assessment have not yet been completed, the initial results confirm the characterization of MPs as an emerging risk in the food chain and establish exposure and uptake route of MPs through the consumption of seafood. These conclusions alone support the 
adoption of the precautionary principle since we are at the moment faced with an uncertain risk (Zander 2010). Our laboratory is in the process of conducting research towards the completion of the risk assessment and the establishment of a causality relationship between exposure to MPs and specific human health effects; if indeed there is one.

\subsection{Summary and conclusions}

Significant differences were observed in the number of particles isolated from typically non edible gills and digestive tissues in the finfish relative to the blanks, but not in the edible flesh. This is important to highlight since published studies analysing whole fish may overestimate the real MP burden in seafood. For scallop, species differences in MP levels were observed, yet each contained MPs and the tissues analysed represent the edible parts. Analysis by FTIR microscopy found that 16-60\% of the particles characterized were made up of MPs with PET and PE most commonly detected. The FTIR findings demonstrate the need to properly characterise the particles or risk overestimation of MP levels, especially with cellulose type items. The literature review, risk identification and initial risk assessment results validate MPs as an emerging risk in the food chain and establish seafood as a vector for the exposure and uptake of MPs through the ingestion route for humans. As such, MP quantification should be included as one of the food safety measures as a preventative measure for shellfish. On the other hand, given the very low MP levels in edible fish flesh, such measures may not be required, as yet, for finfish species. To investigate this further, our current research investigates the presence of MPs in the human digestive system.

\section{Acknowledgements}

This work was completed entirely by postgraduate students while conducting their thesis work at the University of Hull. Jiana Li was funded as a Visiting $\mathrm{PhD}$ student by a China Scholarship Council grant (201606140125) and an East China Normal University Outstanding Doctoral Dissertation Cultivation Plan of Action grant (YB2016035). 


\section{Figure and Table Legends}

Figure 1. Mean relative abundance of particles per gram of tissue from fish and scallop samples. $\mathrm{n}=10$ for fish tissue ( $\mathrm{n}=12$ for haddock), $\mathrm{n}=3$ to 6 for procedural blanks. $\mathrm{n}=10$ for scallops, $\mathrm{n}=9$ for procedural blanks.

Figure 2. Mean relative abundance of particles per individual scallop. PS, Patagonian scallop; SS, Scottish scallop. $\mathrm{n}=10$ for scallops, $\mathrm{n}=9$ for procedural blanks.

Figure 3. Shapes of particles isolated from fish and scallop tissue samples and procedural blank samples.

Figure 4. Distribution of the sizes $(\mathrm{mm})$ of particles found in the fish and scallop tissue and procedural blank samples.

Figure 5. Chemical composition of particles identified in A. Haddock, B. Seabass, C. Mackerel, D. Plaice, E. Scottish scallop, and F. Patagonian scallop. Grid shading represents chemicals that have been identified in all species. Abbreviations: PET, polyethylene terephthalate; PE, polyethylene; PP, polypropylene; PEP, polyethylene:polypropylene copolymer; PEPD, polyethylene:polypropylene:dien; PVAE, polyvinyl acetate:ethylene, PAN, polyacrylonitrile; zein, a maize plant protein.

Figure 6. World map showing the geographic origin of fish investigated for their MP content and the number of species studied at each location. Map locations may be approximations based on information provided in the papers. Red marker $=$ shellfish study, yellow marker $=$ finfish study (Bellas et al. 2016; Boerger at al., 2010; Bonello et al. 2018; Catarino et al. 2018; Davidson and Dudas 2016; De Witte et al. 2014; Foekma et al. 2013; Jabeen et al. 2017; Jantz et al. 2013; Li et al. 2016; Li et al. 2018; Liboiron et al. 2018; Lusher et al. 2013; Mathalon and Hill 2014; Nadal et al. 2016; Naji et al. 2018; Neves et al. 2015; Ory et al. 2017; Phuong et al. 2018; Possatto et al. 2011; 
Rochman et al. 2015; Santana et al. 2016; Tanaka and Takada 2016; Vandermeersch et al. 2015; Van

Cauwenberghe et al. 2015; Welden et al. 2018). Base map: World Map Blank, credit: Petr Dlouhý, CC BY-SA 3.0, via Wiki Commons.

Figure 7. A) ERI procedure diagram for MPs, and B) Risk assessment diagram for MPs in seafood. 


\section{References}

Bellas J, Martínez-Armental J, Martínez-Cámara A, Besada V, Martínez-Gómez C. 2016. Ingestion of microplastics by demersal fish from the Spanish Atlantic and Mediterranean coasts. Mar Pollut Bull 109:55-60, PMID: 27289284, https://doi.org/10.1016/j.marpolbul.2016.06.026

Boerger CM, Lattin GL, Moore SL, Moore CJ. 2010. Plastic ingestion by planktivorous fishes in the North Pacific Central Gyre. Mar Pollut Bull 60:2275-2278, https://doi.org/10.1016/j.marpolbul.2010.08.007

Bonello G, Varrella P, Pane L. 2018. First evaluation of microplastic content in benthic filter-feeders of the Gulf of La Spezia (Ligurian Sea). J Aquatic Food Product Technol 27: 284-291, https://doi.org/10.1080/10498850.2018.1427820

Brate ILN, Hurley R, Iversen K, Beyer J, Thomas KV, Steindal CC, Green NW, Olsen M, Lusher A. 2018. Mytilus spp. As sentinels for moniroting microplastic pollution in Norwegian coastal waters: a qualitative and quantitative study. Environ Pollut 243:383-393, https://doi.org/10.1016/j.envpol.2018.08.77

Browne MA, Dissanayake A, Galloway TS, Lowe DM, Thompson RC. 2008. Ingested microscopic plastic translocates to the circulatory system of the mussel, Mytilus edulis (L.). Environ Sci Technol 42:5026-5031, https://doi.org/10.1021/es800249a

Browne MA, Galloway TS, Thompson RC. 2010. Spatial patterns of plastic debris along estuarine shorelines. Environ Sci Technol 44:3404-3409, https://doi.org/10.1021/es903784e

Catarino AI, Macchia V, Sanderson WG, Thompson RC, Henry TB. 2018. Low levels of microplastics (MP) in wild mussels indicate that MP ingestion by humans is minimal compared to exposure via household fibres fallout during a meal. Environ Pollut 237:675-684, https://doi.org/10.1016/j.envpol.2018.02.069 
Claessens M, Meester DS, Van Landuyt L, Clerck KD, Janssen CR. 2011. Occurrence and distribution of microplastics in marine sediments along the Belgian coast. Mar Pollut Bull 62:2199-2204, https://doi.org/10.1016/j.marpolbul.2011.06.030

Claessens M, Van Cauwenberghe L, Vandegehuchte M, Janssen C. 2013. New techniques for the detection of microplastics in sediments and field collected organisms. Mar Pollut Bull 70:227-233, https://doi.org/10.1016/j.marpolbul.2013.03.009

Cole M, Lindeque P, Halsband C, Galloway TS. 2011. Microplastics as contaminants in the marine environment: A review. Mar Pollut Bull 62:2588-2597, https://doi.org/10.1016/j.marpolbul.2011.09.025

Cole M, Webb H, Lindeque PK, Fileman ES, Halsband C, Galloway TS. 2014. Isolation of microplastics in biota-rich seawater samples and marine organisms. Scientific Rep 4:4528, https://doi.org/10.1038/srep04528

Davidson K, Dudas SE. 2016. Microplastic ingestion by wild and cultured manila clams (Venerupis philippinarum) from Baynes Sound, British Columbia. Arch Environ Contam Toxicol 71:147-156, https://doi.org/10.1007/s00244-016-0286-4

DEFRA 2017. Department for Environment, Food \& Rural Affairs; Family Food 2016/17: Purchases. Available online: https://www.gov.uk/government/publications/ family-food-201617/purchases [Accessed 27-02-2019]

Desforges JPW, Galbraith M, Ross PS. 2015. Ingestion of microplastics by zooplankton in the Northeast Pacific Ocean. Arch Environ Contam Toxicol 69:320-330, https//doi.org/10.1007/s00244-015-0172-5

De Witte B, Devriese L, Bekaert K, Hoffman S, Vandermeersch G, Cooreman K, Robbens J. 2014. Quality assessment of the blue mussel (Mytilus edulis): Comparison between commercial and wild types. Mar Pollut Bull 85:146-155, https://doi.org/10.1016/j.marpolbul.2014.06.006 
EFSA 2014. A systematic procedure for the identification of emerging chemical risks in the food and feed chain. EFSA Supporting Publications, 11(1), 547E. Parma, Italy. Available online: https://www.efsa.europa.eu/en/supporting/pub/ en-547 [Accessed 27-02-2019]

EFSA 2017. Scientific Committee. Update: use of the benchmark dose approach in risk assessment, 15(1), e04658. EFSA Journal 2017;15(1):4658. https://doi.org/10.2903/j.efsa.2017.4658

EFSA 2018. Emerging risks identification on food and feed-EFSA, 16(7), e05359.

EFSA Scientific Committee 2018. Guidance on risk assessment of the application of nanoscience and nanotechnologies in the food and feed chain: Part 1, human and animal health. EFSA Journal, 16(7), e05327. https://doi.org/10.2903/j.efsa.2018.5327

FAO (Food and Agriculture Organization) 2016. Fishery and Aquaculture Country Profiles: The United Kingdom of Great Britain and Northern Ireland. Food and Agriculture Organization of the United Nations. Available online: http://www.fao.org/fishery/facp/GBR/en [Accessed 01-03-2019]

FDA 2002. U.S. Food and Drug Administration. A Report by the CFSAN Risk Analysis Working Group; Initiation and Conduct of All "Major" Risk Assessments within a Risk Analysis Framework. Available online: https://www.fda.gov/Food/FoodScienceResearch/RiskSafetyAssessment/ucm475127.htm\#par ti [Accessed 03-02-2019]

Fendall LS, Sewell MA. 2009. Contributing to marine pollution by washing your face: Microplastics in facial cleansers. Mar Pollut Bull 58:1225-1228, https://doi.org/10.1016/j.marpolbul.2009.04.025

Foekema EM, De Gruijter C, Mergia MT, van Franeker JA, Murk AJ, Koelmans AA. 2013. Plastic in North Sea fish. Environ Sci Technol 47:8818-8824, https://doi.org/10.1021/es400931b

Gallagher A, Rees A, Rowe R, Stevens J, Wright P. 2016. Microplastics in the Solent estuarine complex, U.K.: An initial assessment. Mar Pollut Bull 102:243-249, https://doi.org/10.1016/j.marpolbul.2015.04.002 
GESAMP 2015. Sources, fate and effects of microplastics in the marine environment: a global assessment. Reports and Studies. London: International Maritime Organisation. Available online: http://www.gesamp.org/publications/reports-and-studies-no-90 [Accessed 24-102018]

Giani D, Baini M, Galli M, Casini S, Fossi MC. 2019. Microplastics occurrence in edible fish species (Mullus barbatus and Merluccius merluccius) collected in three different regions of the Mediterranean $\quad$ Sea. Mar Pollut Bull 140:129-137, https://doi.org/10.1016/j.marpolbul.2019.01.005

Gore AC, Chappell VA, Fenton SE, Flaws JA, Nadal A, Prins GS, Toppari J, Zoeller RT. 2015. Executive Summary to EDC-2: The Endocrine Society's Second Scientific Statement on Endocrine-Disrupting Chemicals. Endocrine Rev 36(6):593-602, https://doi.org/10.1210/er.2015-1093

Hartmann NB, Huffer T, Thompson RC, Hassellov M, Verschoor A, Daugaard AE, Rist S, Karlsson T, Brennholt N, Cole M, Herrling MP, Hess MC, Ivleva NO, Lusher AL, Wagner M. 2019. Are we speaking the same language? Recommendations for the definition and categorization framework for plastic debris. Environ Sci Technol 53:1039-1047, https://doi.org/10.1021/acs.est.8b05297

Hermsen E, Pompe R, Besseling E, Koelmans AA. 2017. Detection of low numbers of microplastics in North Sea fish using strict quality assurance criteria. Mar Pollut Bull 122:253-258, https://doi.org/10.1016/j.marpolbul.2017.06.051

Jabeen K, Su L, Li J, Yang D, Tong C, Mu J, Shi H. 2017. Microplastics and mesoplastics in fish from coastal and fresh waters of China. Environ Pollut 221:141-149, PMID: 27939629, https://doi.org/10.1016/j.envpol.2016.11.055

Jantz LA, Morishige CL, Bruland GL, Lepczyk CA. 2013. Ingestion of plastic marine debris by longnose lancetfish (Alepisaurus ferox) in the North Pacific Ocean. Mar Pollut Bull 
69:97-104, PMID: 23465573, https://doi.org/10.1016/j.marpolbul.2013.01.019

Karami A, Golieskardi A, Choo CK, Larat V, Karbalaei S, Salamatinia B. 2018. Microplastic and mesoplastic contamination in tinned sardines and sprats. Sci Tot Environ 612:1380-1386, https://doi.org/10.1016/j.scitotenv.2017.09.005

Kazmiruk TD, Kazmiruk VD, Bendell LI. 2018. Abundance and distribution of microplastics within surface sediments of a key shellfish growing region of Canada. PLOS ONE 13:e0196005, https://doi.org/10.1371/journal.pone.0196005

Khoironi A, Anggoro S, Sudarno S. 2018. The existence of microplastic in Asian green mussels. IOP Conference Series: Earth and Environmental Science 131:012050, https://doi.org/10.1088/1755-1315/131/1/012050

Kristensen P. 2004. The DPSIR Framework. National Environmental Research Institute, Denmark: Department of Policy Analysis European Topic Centre on Water, European Environment Agency.

Law KL, Thompson RC. 2014. Microplastic in the seas. Science 345:144-145, https://doi.org/10.1126/science.1254065

Li J, Qu X, Su L, Zhang W, Yang D, Kolandhasamy P, Li D, Shi H. 2016. Microplastics in mussels along the coastal waters of China. Environ Pollut 214:177-184, PMID: 27086073, https://doi.org/10.1016/j.envpol.2016.04.012

Li J, Yang D, Li L, Jabeen K, Shi H. 2015. Microplastics in commercial bivalves from China. Environ Pollut 207:190-195, https://doi.org/10.1016/j.envpol.2015.09.018

Li J, Green CG, Reynolds A, Shi H, Rotchell JM. 2018. Microplastics in mussels sampled from coastal waters and supermarkets in the United Kingdom. Environ Pollut 241:35-44, PMID: 29793106, https://doi.org/10.1016/j.envpol.2018.05.038

Liboiron F, Ammendolia J, Saturno J, Melvin J, Zahara A, Richárd N, Liboiron M. 2018. A zero percent plastic ingestion rate by silver hake (Merluccius bilinearis) from the south coast of Newfoundland, Canada. Mar Pollut Bull 131:267-275, PMID: 29886947, 
https://doi.org/10.1016/j.marpolbul.2018.04.007

Lusher AL, McHugh M, Thompson RC. 2013. Occurrence of microplastics in the gastrointestinal tract of pelagic and demersal fish from the English Channel. Mar Pollut Bull 67:94-99, https://doi.org/10.1016/j.marpolbul.2012.11.028

Mathalon A, Hill P. 2014. Microplastic fibers in the intertidal ecosystem surrounding Halifax Harbor, Nova Scotia. Mar Pollut Bull 81:69-79, PMID: 24650540, https://doi.org/ $\underline{10.1016 / j . m a r p o l b u l .2014 .02 .018 ~}$

McGoran AR, Clark PF, Morritt D. 2017. Presence of micropastic in the digestive tracts of the European flounder, Platichthys flesus, and the European smelt, Osmerus eperlanus, from the River Thames. Mar Pollut Bull 220:744-751, PMID: 27697381, https://doi.org/10.1016/j.envpol.2016.09.078

Meeker JD, Sathyanarayana S, Swan SH. 2009. Phthalates and other additives in plastics: human exposure and associated health outcomes. Phil Trans Roy Soc B: Biol Sci 364:2097-2113, https://doi.org/10.1098/rstb.2008.0268

Murphy F, Russell M, Ewins C, Quinn B. 2017. The uptake of macroplastic and microplastic by demersal and pelagic fish in the Northeast Atlantic around Scotland. Mar Pollut Bull 122:353-359, PMID: 28705632, https://doi.org/10.1016/j.marpolbul.2017.06.073

Murray F, Cowie PR. 2011. Plastic contamination in the decapod crustacean Nephrops norvegicus (Linnaeus, 1758). Mar Pollut Bull 62:1207-1217, PMID: 21497854 https://doi.org/10.1016/j.marpolbul.2011.03.032

Nadal M, Alomar C, Deudero S. 2016. High levels of microplastic ingestion by the semipelagic fish bogue Boops boops (L.) around the Balearic Islands. Environ Pollut 214:517-523, PMID: 27131810, https://doi.org/10.1016/j.envpol.2016.04.054

Naji A, Nuri M, Vethaak AD. 2018. Microplastics contamination in molluscs from the northern part of the Persian Gulf. Environ Pollut 235:113-120, PMID: 29276957 https://doi.org/10.1016/j.envpol.2017.12.046 
Neves D, Sobral P, Ferreira JL, Pereira T. 2015. Ingestion of microplastics by commercial fish off the Portuguese coast. Mar Pollut Bull 101:119-126, PMID: $\underline{26608506}$ https://doi.org/10.1016/j.marpolbul.2015.11.008

Nor NHM, Obbard JP. 2014. Microplastics in Singapore's coastal mangrove ecosystems. Mar Pollut Bull 79:278-283, https://doi.org/10.1016/j.marpolbul.2013.11.025

Ory NC, Sobral P, Ferreira JL, Thiel M. 2017. Amberstripe scad Decapterus muroadsi (Carangidae) fish ingest blue microplastics resembling their copepod prey along the coast of Rapa Nui (Easter Island) in the South Pacific subtropical gyre. Sci Tot Environ 586:430-437, PMID: 28196756, https://doi.org/10.1016/j.scitotenv.2017.01.175

Phuong NN, Zalouk-Vergnoux A, Kamari A, Mouneyrac C, Amiard F, Poirier L, Lagarde F. 2018. Quantification and characterization of microplastics in blue mussels (Mytilus edulis): protocol setup and preliminary data on the contamination of the French Atlantic coast. Environ Sci Pollut Res 25:6135-6144, PMID: 28382446, https://doi.org/10.1007/s11356-017-8862-3

Possatto FE, Barletta M, Costa MF, Ivar do Sul JA, Dantas DV. 2011. Plastic debris ingestion by marine catfish: An unexpected fisheries impact. Mar Pollut Bull 62:1098-1102, PMID: $\underline{21354578}, \underline{\text { https://doi.org/10.1016/j.marpolbul.2011.01.036 }}$

Reguera P, Vinas L, Gago J. 2019. Microplastics in wild mussels (Mytilus spp.) from the North coast of Spain. Scientia Mar 83:337-347, https://doi.org/10.3989/scimar.04927.05A

Richardson L (eds.), Dixon S, Elliott M, Ellis G, Holden J, Murray A, Pilkington J, Reade S, Williamson K, Wintz P. 2016. UK Sea Fisheries Statistics 2016. Marine Maritime Organisation, p.109.

Roch S, Walter T, Ittner L, Freidrich C, Brinker A. 2019. A systematic study of the microplastic burden in freshwater fishes of south-western Germany - are we searching at the right scale? Sci Tot Environ 689:1001-1011, https://doi.org/10.10.16/j.scitotenv.2019.06.404

Rochman CM, Tahir A, Williams SL, Baxa DV, Lam R, Miller JT, Teh F, Werorilangi S, Teh SJ. 2015. Anthropogenic debris in seafood: Plastic debris and fibers from textiles in fish and 
bivalves sold for human consumption. Scientific Rep 5:1-10, https://doi.org/10.1038/srep14340

Rummel CD, Löder MG, Fricke NF, Lang T, Griebeler EM, Janke M, Gerdts G. 2016. Plastic ingestion by pelagic and demersal fish from the North Sea and Baltic Sea. Mar Pollut Bull 102:134-141, PMID: 26621577, https://doi.org/10.1016/j.marpolbul.2015.11.043

Ryan PG, Moore CJ, van Franeker JA, Moloney CL. 2009. Monitoring the abundance of plastic debris in the marine environment. Phil Trans Roy Soc B: Biol Sci 364:1999-2012, https://doi.org/10.1098/rstb.2008.0207

de Sá LC, Luís LG, Guilhermino L. 2015. Effects of microplastics on juveniles of the common goby (Pomatoschistus microps): Confusion with prey, reduction of the predatory performance and efficiency, and possible influence of developmental conditions. Environ Pollut 196:359-362, PMID: 25463733, https://doi.org/10.1016/j.envpol.2014.10.026

Santana MFM, Ascer LG, Custódio MR, Moreira FT, Turra A. 2016. Microplastic contamination in natural mussel beds from a Brazilian urbanized coastal region: Rapid evaluation through bioassessment. Mar Pollut Bull 106:183-189, PMID: 26980138, https://doi.org/10.1016/j.marpolbul.2016.02.074

SCENIHR (Scientific Committee on Emerging and Newly Identified Health Risks) 2012. Memorandum on the use of the scientific literature for human health risk assessment purposes-weighing of evidence and expression of uncertainty. European Union. Available online: https://www.ices-emfsafety.org/wp-content/uploads/2014/11/scenihr.pdf [Accessed 03-02-2019]

Scott N, Porter A, Santillo D, Simpson H, Lloyd-Williams S, Lewis C. 2019. Particle characteristics of microplastics contaminating the mussel Mytilus edulis and their surrounding environments. Mar Pollut Bull 146:125-133, https://doi.org/10.1016/j.marpolbul.2019.05.041

Setälä O, Fleming-Lehtinen V, Lehtiniemi M. 2014. Ingestion and transfer of microplastics in the planktonic food web. Environ Pollut 185:77-83, PMID: 24220023, 
https://doi.org/10.1016/j.envpol.2013.10.013

Steer M, Cole M, Thompson RC, Lindeque PK. 2017. Microplastic ingestion in fish larvae in the western English Channel. Environ Pollut 226:250-259, PMID: 28408185, https://doi.org/10.1016/j.envpol.2017.03.062

Su L, Deng H, Li B, Chen Q, Pettigrove V, Wu C, Shi HH. 2019. The occurrence of microplastic in specific organs in commercially caught fishes from coast and estuary area of east China. $\mathbf{J}$ Haz Mat 365:716-724, https://doi.org/10.1016/j.jhazmat.2018.11.024

Tagg AS, Sapp M, Harrison JP, Ojeda JJ. 2015. Identification and quanitification of microplastics in wastewater using focal plane array-based reflectance micro-FT-IR imaging. Anal Chem 87:6032-6040, https://doi.org/10.1021/acs.analchem.5b00495

Tanaka K, Takada H. 2016. Microplastic fragments and microbeads in digestive tracts of planktivorous fish from urban coastal waters. Scientific Rep 6:1-8, https://doi.org/10.1038/srep34351

The Food Safety and Hygiene (England) Regulations. 2013. The Stationery Office Limited. Available online: http://www.legislation.gov.uk/uksi/2013/2996/contents/made [Accessed 12-02-2019]

The General Food Regulations. 2004. The Stationery Office Limited. Available online: http://www.legislation.gov.uk/uksi/2004/3279/made [Accessed 12-02-2019].

Thompson RC, Olsen Y, Mitchell RP, Davis A, Rowland SJ, John AWG, McGonigle D, Russell AE. 2004. Lost at sea: where is all the plastic? Science 304:838-838, https://doi.org/10.1126/science.1094559

Van Cauwenberghe L, Claessens M, Vandegehuchte MB, Janssen CR. 2015. Microplastics are taken up by mussels (Mytilus edulis) and lugworms (Arenicola marina) living in natural habitats. Environ Pollut 199:10-17, PMID: 25617854, https://doi.org/10.1016/j.envpol.2015.01.008

Van Cauwenberghe L, Janssen CR. 2014. Microplastics in bivalves cultured for human consumption. $\quad$ Environ $\quad$ Pollut 193:65-70, $\quad$ PMID: 
https://doi.org/10.1016/j.envpol.2014.06.010

Vandermeersch G, Van Cauwenberghe L, Janssen CR, Marques A, Granby K, Fait G, Kotterman MJJ, Diogène J, Bekaert K, Robbens J, Devriese L. 2015. A critical view on microplastic quantification in aquatic organisms. Environ Res 143:46-55, PMID: 26249746, https://doi.org/10.1016/j.envres.2015.07.016

von Moos N, Burkhardt-Holm P, Köhler A. 2012. Uptake and effects of microplastics on cells and tissue of the blue mussel Mytilus edulis L. after an experimental exposure. Environ Sci Technol 46:11327-11335, PMID: 22963286, https://doi.org/10.1021/es302332w

Welden NA, Abylkhani B, Howarth LM. 2018. The effects of trophic transfer and environmental factors on microplastic uptake by plaice, Pleuronectes plastessa, and spider crab, Maja squinado. Environ $\quad$ Pollut 239:351-358, 29674213 , https://doi.org/10.1016/j.envpol.2018.03.110

Waller CL, Griffiths HJ, Waluda CM, Thorpe SE, Loaiza I, Moreno B, Pacherres CO, Hughes KA. 2017. Microplastics in the Antarctic marine system: An emerging area of research. Sci Tot Environ 598:220-227, https://doi.org/10.1016/j.scitotenv.2017.03.283

Wright SL, Thompson RC, Galloway TS. 2013. The physical impacts of microplastics on marine organisms: A review. Environ Pollut 178:483-492, PMID: 23545014, https://doi.org/10.1016/j.envpol.2013.02.031

Zander J. 2010. The application of the precautionary principle in practice [electronic resource] : comparative dimensions. Cambridge, New York: Cambridge University Press.

Zhu L, Wang H, Chen B, Sun X, Qu K, Xia B. 2019. Microplastic ingestion in deep-sea fish from the South China Sea. Sci Tot Environ 677:493-501, https://doi.org/10.1016/j.scitotenv.2019.04.380 